\title{
Introduction \\ How to Read The Souls of Black Folk in a Post-Racial Age
}

JONATHAN SCOTT HOLLOWAY

\section{An Intellectual Biography}

I sit with Shakespeare and he winces not. Across the color line I move arm in arm with Balzac and Dumas, where smiling men and welcoming women glide in gilded halls. From out the caves of evening that swing between the strong-limbed earth and the tracery of the stars, I summon Aristotle and Aurelius and what soul I will, and they come all graciously with no scorn nor condescension.

w. E. B. DU BOIs, "Of the Training of Black Men"

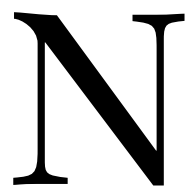

ew Englander. Middle-class uplift ideologist. Polemicist. Urban sociologist. Southerner. Pan-Africanist. Assimilationist. Professor. Elitist. Civil rights agitator. Editor. Novelist. Progressive. Antinuclear peace activist. Suspect. Figurehead. Communist. Ghanaian.

Each of these words describes William Edward Burghardt Du Bois at some point in his life. Born in Great Barrington, Massachusetts, in 1868, W. E. B. Du Bois (pronounced doo-boys by his family) 
is one of the most important and endlessly intriguing figures in the history of post-emancipation letters and politics. Perhaps most famous for his principled stand against Booker T. Washington's political philosophy of racial accommodation, Du Bois also established new fields of scholarly inquiry, helped lead one of the first cultural societies for black intellectuals, and mentored several generations of black scholars and activists. His engagement with civil rights battles took shape when he helped establish the Niagara Movement in 1905 and the National Association for the Advancement of Colored People (NAACP) in 19og. Although he came to have a complicated relationship with the NAACP decades after its founding, Du Bois's importance to the history of the fight for full civil rights was always evident to the movement's most prominent leaders. One dramatic moment makes this clear: On the morning of the March on Washington for Jobs and Freedom, Roy Wilkins, head of the NAACP, walked to the podium and announced to the 250,000 protestors that $\mathrm{Du}$ Bois had died the night before in Ghana. Wilkins said, "Regardless of the fact that in his later years Dr. Du Bois chose another path, it is incontrovertible that at the dawn of the twentieth century his was the voice that was calling to you to gather here today in this cause. If you want to read something that applies to 1963 go back and get a volume of The Souls of Black Folk by Du Bois published in 1903."

The Souls of Black Folk is one of the few indisputable masterpieces in the African American literary canon. When the still-young Du Bois, only thirty-five, published this book, he made a major mark in the world of black arts and letters. Since Du Bois was never one to underestimate his value, it is tempting to say that he knew what he had accomplished in writing the book. It is difficult to imagine, however, that Du Bois could have foreseen that The Souls of Black Folk-part prose poem, part sociological tract, part memoir, part short story, part manifesto, part eulogy—would become as important and as long-lasting as it has. ${ }^{2}$

The book's significance is easy to understand given Du Bois's involvement in so much of twentieth-century African American 
thought and political activism. Although The Souls of Black Folk was not his first book, it was the text through which Du Bois emerged as a major force in the central debates about African American civil and human rights. The powerful indictment of turn-of-the-century conservative accommodationist politics that he made in the book reinforced the central role that uplift philosophy would play in middle-class black social and political circles for decades to come. His interdisciplinary approach to describing black life meant that the book would have enduring value to future generations of scholars who wanted to speak to the centrality of black life in music, literary arts, and the sociological imagination. (Du Bois's radical cultural intellectual project is evident even in the layout of the book. Each chapter opens with two epigraphs: a prose sampling from the European canon and an excerpt from a Negro spiritual. Du Bois did not wince when he put these cultural exemplars next to each other and insisted that his reader understand the juxtaposition as one of equals, of cultural products that informed each other.)

The Souls of Black Folk may occupy a special place of enduring value in the scholarly world, but what is its relevance beyond the ivory tower? After all, there is no denying that much has changed in the decades since Du Bois's assessments and prognostications. Although he died on the cusp of some of the most-marked changes - the passage of the Civil and Voting Rights Acts, federal housing reform, the institutionalization (albeit fading in our contemporary moment) of affirmative action in industry, government, and universities-and only a few decades before the election of an African American president, Du Bois was able to see a decolonizing Africa and the opening of possibilities for the future. Given the domestic and international changes and a rising suggestion that we in the twenty-first century are in a "post-racial age," some might conclude that The Souls of Black Folk is a relic, a primary source for the exclusive use of scholars who want to better understand a specific moment in time. Before picking up the book the contemporary reader might even wonder if The Souls of Black Folk is still predictive of structures of power and 
cultural interaction and might dismiss the idea that it has an abiding relevance to a broad public.

This dismissal would be hasty.

Just as Roy Wilkins reminded the protestors assembled on the Washington Mall to read Du Bois's masterpiece if they wanted to understand the long history of the country's civil rights struggles, we, too, find understanding in The Souls of Black Folk: it still speaks to us today and to our current condition. Even in light of the real changes since the book was originally published, declarations that we are presently somehow "post-racial" create cognitive dissonance. A roll call of racially informed incidents concerning citizenship, labor, education, pathology, and violence-all of which are topics in Du Bois's book-are even now being read into our collective consciousness, and debates about the legacies of racial slavery, which many consider our nation's original sin, fill the pages of our mainstream press and the World Wide Web. ${ }^{3}$

For Du Bois, race does not extend beyond human logic. Rather, he points out in The Souls of Black Folk time and again how legacies of social, political, and economic practices took on a racial veneer and how these appropriations were the result of considered choices. There are those who would prefer race to go away (when affirmative action policies create racial "preferences," for example). The idea that race is a human construction suggests to them that humans, at least those in the United States, can unmake, and actually have unmade, something that was made at the country's founding. But a close reading of The Souls of Black Folk uncovers how the constructed idea of race separates people and how it imbues what this country has been and, in truth, remains.

When we think about the processes and permanencies of racial construction, The Souls of Black Folk is uniquely helpful because of the way it charts Du Bois's own evolving racial consciousness. In the book's earliest pages we discover that Du Bois, the great "race man," the preeminent black intellectual of the twentieth century, was not born to a racial mission. His racial sensibility was learned. And de- 
spite real changes in material possibilities for so many in this country, the forces that inform racial perspectives have not fundamentally changed since The Souls of Black Folk's original publication. The book stands as a melancholy assertion that a "post-racial" consciousness is a false consciousness.

A survey of Du Bois's early years reveals a talented and driven boy who, by the circumstances of his upbringing, grew into a raceconscious young man. He was raised in Great Barrington amid a polyglot community of immigrants and led a fairly mundane and, in that way, idyllic life. He was undoubtedly aware of the racial differences in Great Barrington-there were only a few dozen black people in a community of five thousand-but he and his mother were welcomed and supported by leading white figures (the pastor of the Congregationalist Church, the principals of two different schools), and Great Barrington would always figure as a grounding presence in his life. ${ }^{4}$

Despite earning the admiration and respect of many in Great Barrington, Du Bois learned at an early age that his success was contingent upon the goodwill of peers. In the opening paragraphs of "Of Our Spiritual Strivings," the first chapter of The Souls of Black Folk, Du Bois recounts discovering how racial difference would affect his life and introduces the central metaphor of his book: the racial "veil" that separates white from black. He writes about a "merry" day of exchanging visiting cards with classmates until a girl, new to town, refused to accept his. It was at that moment when "the shadow swept across me": it "dawned upon me with a certain suddenness that I was different from the others . . . shut out from their world by a vast veil."

Du Bois makes great use of this childhood story and the newcomer's discourteousness. He explains how other moments like this drove him to excel in every task, always eager to disprove the presumed merit of the racial veil. "I had thereafter," he remembers, "no desire to tear down that veil, to creep through; I held all beyond it in common contempt, and lived above it in a region of blue sky and great wandering shadows. That sky was bluest when I could beat my 
mates at examination-time, or beat them at a foot-race, or even beat their stringy heads. Alas, with the years all this fine contempt began to fade; for the worlds I longed for, and all their dazzling opportunities, were theirs, not mine. But they should not keep these prizes, I said; some, all, I would wrest from them."

As he headed further into his teenage years the ambitious Du Bois concluded that he would best his peers in the world of ideas. To that end he set his sights on Harvard. His mentors were concerned that the Great Barrington schools had not properly prepared Du Bois for the rigors of Harvard and suggested that he pursue studies at Fisk University, in Nashville, Tennessee. Although in later years people saw him as fundamentally dedicated to improving the quality of African American life, Du Bois's move to Fisk was his first enduring encounter with a large black population and his first experience in the South.

Du Bois's four years at Fisk clearly affected him. The indignities he suffered in his childhood town paled when compared to what he witnessed, and endured, in the South. In The Souls of Black Folks, Du Bois spends several chapters ("Of the Wings of Atalanta," "Of the Black Belt," "Of the Quest of the Golden Fleece," "Of the Sons of Masters and Man") moving from clinical examinations of southern history, politics, and labor to pained observations of racial violence, penury, and broken dreams. Just one paragraph from "Of the Black Belt" captures the disparities in the region:

It is a land of rapid contrasts and of curiously mingled hope and pain. Here sits a pretty blue-eyed quadroon hiding her bare feet; she was married only last week, and yonder in the field is her dark young husband, hoeing to support her, at thirty cents a day without board. Across the way is Gatesby, brown and tall, lord of two thousand acres shrewdly won and held. There is a store conducted by his black son, a blacksmith shop, and a ginnery. Five miles below here is a town owned and controlled by one white New Englander. He owns almost a Rhode Island county, with thousands of acres and hundreds of black laborers. Their cabins look better than most, and the farm, with 
machinery and fertilizers, is much more business-like than any in the county, although the manager drives hard bargains in wages. When now we turn and look five miles above, there on the edge of town are five houses of prostitutes,- - two of blacks and three of whites; and in one of the houses of the whites a worthless black boy was harbored too openly two years ago; so he was hanged for rape. And here, too, is the high whitewashed fence of the "stockade," as the county prison is called; the white folks say it is ever full of black criminals, - the black folks say that only colored boys are sent to jail, and they not because they are guilty, but because the State needs criminals to eke out its income by their forced labor.

Bearing witness to such radical disparities and to so much wasted human potential moved Du Bois to accept a call to service on behalf of his race. He believed that he should continue his education and thus become a "missionary of culture to an untaught people," as he writes in "Of the Wings of Atalanta." Du Bois's childhood determination to prove himself better than his peers became wrapped up in his scholarly accomplishments, and he fixed his vision on carrying the race forward not so much on his shoulders as in his broad wake.

After graduating from Fisk in 1888, Du Bois matriculated as a junior at Harvard (his years at Fisk having now prepared him for the challenges at Harvard, according to the logic of that school's admissions officers); he remained in Cambridge for graduate study. By the time he received his $\mathrm{PhD}$ in 1895-the first African American to earn that degree at Harvard-he had spent two years at the University of Berlin on a fellowship and had started teaching at Wilberforce University, in Ohio. His dissertation, The Suppression of the African Slave Trade to the United States of America, 1638-1870, was the first book published in the vaunted Harvard Historical Studies series.

With a degree in hand and a major publication in the works Du Bois seemed about to start a pathbreaking career at one of the nation's leading research universities. This still seemed to be the case when the University of Pennsylvania hired him away from Wilberforce as an assistant in sociology. Du Bois was brought to Penn to 
conduct an extended research study of Philadelphia's black neighborhoods, then the largest in the country. When he completed and published his study, The Philadelphia Negro, Du Bois expected to be offered a teaching position in recognition of his accomplishment-a task for which he was perfectly suited. He believed that his methodology opened up entirely new ways of conducting sociological research and highlighted important socioeconomic issues that were hobbling black Philadelphians and keeping them from fulfilling their potential. The leadership at the university, however, thanked him for his work and declined to offer him a continuing position. Du Bois never got over the perceived snub. Even though the executive leadership at Penn failed to appreciate the value of Du Bois's research, he is recognized today for creating the field of urban ethnography and reshaping the way the sociological study of cities could be conducted.

While Du Bois was in the midst of his research and writing for The Philadelphia Negro, he became engaged in another intellectual project: helping to establish the American Negro Academy (ANA). The ANA, founded in 1897, was conceived in response to a shift in the orientation of black leadership in the waning days of the nineteenth century. Frederick Douglass died in February 1895, and with his passing, black Americans lost their leading voice for full citizenship rights. Just a few months after Douglass's death, Booker T. Washington, the founder and head of the Tuskegee Institute, shot to prominence with his oration at the Atlanta Cotton States and International Exposition, where he advocated an economic and racial peace that, to his critics, consigned blacks to a permanent secondclass status. The Supreme Court was then just one year away from offering its decision in Plessy v. Ferguson that racial segregation was constitutional (the "separate but equal" doctrine remained in place until the Supreme Court reversed course in 1954 with its decision in Brown v. Board of Education).

The first president of the ANA was Alexander Crummell, the septuagenarian priest and former missionary who had moved to Washington, DC, and established St. Luke’s Episcopal Church in 1875 . 
Crummell died just one year after he founded the ANA, but over the last two decades of his life he had dedicated himself to speaking about the moral obligation that men of character, refinement, and education had to serve and save the race. The ANA was a small organization-its membership was limited to twenty-five "leading men of the race"-but Du Bois believed deeply in the mission and, even more, shared Crummell's faith that intellectuals were of fundamental importance to the race's salvation. Scholars, after all, had "secured the vision which penetrates the center of nature."

Du Bois showed his commitment to this ideal by agreeing to serve as the ANA's first vice president (he became president after Crummell's death). The same commitment is captured in a closing chapter of The Souls of Black Folk, where he eulogizes his mentor:

The more I met Alexander Crummell, the more I felt how much that world was losing which knew so little of him. In another age he might have sat among the elders of the land in purple-bordered toga; in another country mothers might have sung him to the cradles.

He did his work, - - he did it nobly and well; and yet I sorrow that here he worked alone, with so little human sympathy. His name today, in this broad land, means little, and comes to fifty million ears laden with no incense of memory or emulation. And herein lies the tragedy of the age: not that men are poor,-all men know something of poverty; not that men are wicked,-who is good? not that men are ignorant,-what is Truth? Nay, but that men know so little of men.

Crummell and Du Bois were so driven to state their case about the role of the intellectual because Washington's rise in the wake of his famous Atlanta Cotton Exposition address threatened their vision of the race's future. Where Washington called for racial appeasement, urging southern planters and northern industrialists to invest in the docile black labor force with its proven loyalty and reassuring them that these same blacks would abide by a logic that preserved the separation of the races, Crummell and Du Bois saw the fashioning of a permanent underclass. Du Bois first aired his views of Washington in 
a 1901 review of Washington's Up from Slavery, but his challenge to Washington's advocacy did not appear fully formed until The Souls of Black Folk was published in 1903. Then it very quickly became the defining assessment of the limits of Washingtonian philosophy. ${ }^{6}$

In stating, in the chapter "Of Mr. Booker T. Washington and Others," that it was time to speak "in all sincerity and utter courtesy of the mistakes and shortcomings of Mr. Washington’s career," Du Bois invoked a moral urgency about the role of the intellectual, investing him (and it was solely a male's role at this point in Du Bois's construction) with a duty to stand up to the dangerous inadequacies of vocational education. The imprint of Crummell's ideology was plain to see: "In failing thus to state plainly and unequivocally the legitimate demands of their people, even at the cost of opposing an honored leader, the thinking classes of American Negroes would shirk a heavy responsibility,- - a responsibility to themselves, a responsibility to the struggling masses, a responsibility to the darker races of men whose future depends so largely on this American experiment, but especially a responsibility to this nation,- - this common Fatherland."

Du Bois criticized a Washingtonian logic that led to "1. The disfranchisement of the Negro. 2. The legal creation of a distinct status of civil inferiority for the Negro. 3. The steady withdrawal of aid from institutions for the higher training of the Negro." Du Bois said that his fellow intellectuals were morally obliged to stand up to Washington: "We have no right to sit silently by while the inevitable seeds are sown for a harvest of disaster to our children, black and white." Strong words for a still-new professor who was currently holding his first full-time faculty position.

Soon after Du Bois apprehended that his research assistantship at Penn would not be extended or formalized into a faculty position, he looked for other employment. After completing some consultant work for the Bureau of Labor Statistics-Du Bois had become quite adept at survey and statistical work through his research for The Philadelphia Negro — he accepted a position at Atlanta University. The thirteen years that Du Bois spent there (1897-1910) represented 
one of the high-water periods in his lengthy career. Indeed, looking back on his time at Atlanta, then one of three great historically black universities in the country (Fisk and Howard being the other two), Du Bois expressed fondness for its stimulating intellectual environment even though he tempered his enthusiasm with recollections of the tightrope that blacks had to walk while living in the Deep South.

It is during his time at Atlanta that Du Bois probably came closest to realizing the ideals that he and Crummell articulated in the American Negro Academy and that Du Bois reasserted multiple times in The Souls of Black Folk. The work that Du Bois pursued at Atlanta was scholarship with a purpose. Through his leadership of the Atlanta University Studies, a series of publications that grew out of themed annual conferences at the school, Du Bois undertook a systemic examination of black life, always with an eye to finding ways to improve the quality of that life. The titles of the studies show the subjects of exploration: The Negro in Business, The Negro Common School, The Negro Artisan, The College-Bred Negro, The Negro Church, and so on.

Du Bois's satisfaction with his years at the university sprang from his intellectual fervor and engagement. While teaching in Atlanta he assumed the presidency of the ANA, organized the Atlanta University Studies, articulated his soon-to-be famous vision for "the talented tenth" (in an essay of the same name, in a book edited by none other than Booker T. Washington), published The Souls of Black Folk, and helped organize the Niagara Movement and then the National Association for the Advancement of Colored People. By the end of this remarkably fertile period Du Bois was the first director of publicity and research for the NAACP, where one of his principal duties was to edit its magazine, The Crisis. He left Atlanta in the summer of 1910 to take the new job. Although the NAACP was officially nonpartisan, Du Bois used his editorial position to advocate for a range of causes over the next two decades. He rallied blacks to support the war effort in 1918 and, a year later, when blacks' patriotic sacrifices garnered no positive change in their citizenship status, told them to 
fight instead for their civil rights at home. In the 1920s, Du Bois used the magazine to cultivate a new generation of artists, thereby playing a significant role in shaping the New Negro Renaissance.

Du Bois resigned from the NAACP in 1934 following a series of disagreements with the new executive director, Walter White, and returned to Atlanta University. Ever the nimble thinker, Du Bois was now developing a Marxist critique of US history and advocating Washingtonian ideas of racially separate economic cooperatives. Du Bois did not last a decade at Atlanta this time around; the trustees refused to extend his contract beyond 1944, and the president of the university quietly hoped that Du Bois would retire. He returned to the NAACP, but left again five years later, when his open allegiances and friendships with individuals who were members of the Communist Party threatened to bring heightened FBI scrutiny of the civil rights group.

Decades before Du Bois's ideas and activities caught the attention of the FBI and even before The Souls of Black Folk was published, Du Bois understood that the "Negro problem in America" was part of a global phenomenon of structured denials of opportunity to second-class, racialized citizens. For example, in 1900 he helped lead the first Pan-African Conference (during which he called on European powers to grant their colonies the right to self-govern) and also curated a major photographic show, "Exhibit of American Negroes," for the Paris Exposition. His subsequent leadership role in the Pan-African Congresses in the 1910s and 1920s and his 1928 novel, Dark Princess (which spoke to the international dimensions of racial citizenship), affirmed his global sensibilities. In the mid-1940s the intensity of Du Bois's focus on international affairs heightened. He offered a sharp critique of colonialism at the founding conference of the United Nations, helped organize the fifth (and final) PanAfrican Congress, charged the United States with committing acts of racial genocide, and became an outspoken peace advocate and antinuclear activist.

Already the subject of an FBI investigation before articulating his 
position against nuclear weapons, Du Bois fell under increased scrutiny and had his passport revoked in $195^{\circ}$. He was unable to leave the country for eight years. When the State Department gave his passport back, Du Bois set off on an international tour and was hailed by heads of state in the Communist world. Finally giving up hope that the United States would ever live up to its democratic ideals, Du Bois declared himself a Communist in 1961, moved to Ghana, where he was personally welcomed by Kwame Nkrumah—-the first leader of that newly independent country — and then gave up his American citizenship when the United States refused to renew his passport once it expired.

Du Bois died in Accra on August 27, 1963. He was ninety-five years old. Nkrumah, who had met Du Bois in Manchester, England, at the fifth Pan-African Congress eighteen years earlier, organized a state funeral for this New England-born Ghanaian citizen who had become an internationally renowned activist and intellectual.

\title{
A Critical Intellectual History
}

\begin{abstract}
Surely there shall yet dawn some mighty morning to lift the Veil and set the prisoned free. Not for me,-I shall die in my bonds,but for fresh young souls who have not known the night and waken to the morning; a morning when men ask of the workman, not "Is he white?" but "Can he work?" When men ask artists, not "Are they black?" but "Do they know?" Some morning this may be, long, long years to come. But now there wails, on that dark shore within the Veil, the same deep voice, Thou shalt forgo!

w. E. B. DU Bois, "Of the Passing of the First-Born"
\end{abstract}

Du Bois's intellectual biography reveals a man who felt comfortable linking the world of ideas and the world of action. It also reveals a man who was not afraid to make major predictive pronouncements about the problems of the age. Even though his ideas shifted over time- - his disdain for any form of racial separatism modulated; his 
antiwar commitments ebbed and flowed in their intensity; his sense of the analytic and explanatory tension between class and race fluctuated-Du Bois was always supremely certain of his ideas in the moment of their expression.

That confidence is found in the opening chapters of The Souls of Black Folk. There, in "Of Our Spiritual Strivings," Du Bois offers a question and an analysis and, in "Of the Dawn of Freedom," a declaration that, taken together, set the tone for the rest of the book. (Indeed, the declaration appears even earlier, in "The Forethought.") Since these introductory salvos have commanded readers' attention in the one hundred-plus years since the book's publication, a critical reading of The Souls of Black Folk needs to start with them. All three help us understand the enduring relevance of book.

The question:

Between me and the other world there is ever an unasked question: unasked by some through feelings of delicacy; by others through the difficulty of rightly framing it. All, nevertheless, flutter around it. They approach me in a half-hesitant sort of way, eye me curiously or compassionately, and then, instead of saying directly, How does it feel to be a problem? they say, I know an excellent colored man in my town; or, I fought at Mechanicsville; or, Do not these Southern outrages make your blood boil? At these I smile, or am interested, or reduce the boiling to a simmer, as the occasion may require. To the real question, How does it feel to be a problem? I answer seldom a word.

The analysis:

After the Egyptian and Indian, the Greek and Roman, the Teuton and Mongolian, the Negro is a sort of seventh son, born with a veil, and gifted with second-sight in this American world, - a world which yields him no true self-consciousness, but only lets him see himself through the revelation of the other world. It is a peculiar sensation, this double-consciousness, this sense of always looking at one's self 
through the eyes of others, of measuring one's soul by the tape of a world that looks on in amused contempt and pity. One ever feels his twoness,-an American, a Negro; two souls, two thoughts, two unreconciled strivings; two warring ideals in one dark body, whose dogged strength alone keeps it from being torn asunder.

The declaration:

The problem of the twentieth century is the problem of the colorline,- - the relation of the darker to the lighter races of men in Asia and Africa, in America and the islands of the sea.

In these three passages, Du Bois references the painful question that suggests an unyielding dysfunction, "How does it feel to be a problem?"; he points to blacks' peculiar gift of "double-consciousness" and implies their simultaneous invisibility and hypervisibility; and he concludes that race consciousness, the "color-line," was going to be the defining characteristic of the century ahead. Because these assertions strike at the foundational logic of this country, The Souls of Black Folk has a long history of being put to use, not just read.

In the late 196os and early 1970 os the nation's historically white universities were undergoing significant changes as they increasingly welcomed black students and then black faculty to their campuses. As blacks began to teach "black courses" they faced the challenge of developing reading lists with in-print material. The Souls of Black Folk filled a void; new editions appeared with startling frequency. Between 1965 and 1979, for example, The Souls of Black Folk was reprinted seven times. If the first twenty-two editions of the original publication did not already make the case, the subsequent eleven editions (four other editions were published between 1938 and 1965) did: The Souls of Black Folk was an urtext for African American arts and letters. ${ }^{7}$

The 1990 s witnessed a new surge of interest in the book, one that paralleled the era's great culture wars and the rising calls for multi- 
cultural education. ${ }^{8}$ Indeed, the book was reprinted thirteen times between 1989 and 1999. It was during this phase in the book's history that Du Bois's invocation of double-consciousness rang loudest.

A new round of editions (and related scholarship) appeared in connection with the hundredth anniversary of the publication of The Souls of Black Folk. Unsurprisingly, the books and essays addressed Du Bois's claim that it was necessary to understand the centrality of the color-line in order to understand the twentieth century. Their authors affirmed the clarity of Du Bois's assertion while also pointing to Du Bois's ideas as laying the groundwork for the current interest in the Black Atlantic world and transnationalism. ${ }^{9}$

Even though the question, the analysis, and the declaration at the beginning of The Souls of Black Folk have sustained the interest of scholars in different eras, the book demands that we also pay attention to it for its contributions to understanding issues that transcend eras.

There are many ways to understand how race intersects with the workings of the United States. The very meaning and relevance of race has been adjudicated in legislatures and courts throughout the country's history. Racial barriers (and the occasional bridge) have been intrinsic to the story of labor and work and the subsequent access to the full rights and privileges of citizenship. Violence-the most upsetting mode of marking territory, claiming justice, and defining the boundaries of access and citizenship—-has often been delineated along racial lines.

Du Bois saw all of this. And when we read his insights into the country's education system, the role of labor, and the utility of violence, we, too, can see race informing them all, intertwining them all. We can see race at work in the past; we can see it at work in the present.

Du Bois never wavered in his commitment to the importance of higher education and the need for blacks to have access to the very finest institutions of learning. What many do not realize, however, is that Du Bois was similarly consistent in his advocacy for differ- 
ent types of education. He did not believe that all blacks needed to pursue $\mathrm{PhDs}$ and live the life of the mind. Rather, he felt that most blacks needed a high-quality vocational education so that they could be prepared for the changing demands of industry. (As he puts it in his chapter "Of the Wings of Atalanta," a discussion about the role of higher education in the black world: "Teach workers to work. . . . Teach thinkers to think." $)^{10}$

Education was directly linked to labor, and there, too, race played a critical role. Du Bois understood that even asking for a welldeveloped system of vocational training was to ask too much of the employing classes. Whites, he knew, looked down their collective noses at black workers, believing that they were ill equipped for the challenges of anything but the most menial types of labor. Du Bois challenged whites' perceptions that blacks were "shiftless" or "lazy." He could see the structural inequities that resulted in blacks' poor efforts, which white employers were apparently unable to see for themselves. As Du Bois wrote in "Of the Quest of the Golden Fleece," black workers

are careless because they have not found that it pays to be careful; they are improvident because the improvident ones of their acquaintance get on about as well as the provident. Above all, they cannot see why they should take unusual pains to make the white man's land better, or to fatten his mule, or save his corn. On the other hand, the white land-owner argues that any attempt to improve these laborers by increased responsibility, or higher wages, or better homes, or land of their own, would be sure to result in failure.

Lowered expectations about what was possible for blacks wrought spectacular damage in the black community. But such expectations did not operate in a vacuum. Rather, they were wed to structural inequalities that guaranteed a second-class citizenship. When blacks decided to push back against these expectations and inequities, whites were prepared to remind blacks of their place in the 
socioeconomic-political system. Depending on the era, the reminders might involve the whip, the rope, or the mob.

In the penultimate chapter of The Souls of Black Folk, Du Bois addresses racial violence. In his parable "Of the Coming of John” he writes about two southern playmates, both named John, one black and one white. As the two children grow into adulthood their paths diverge until, through vicious coincidence, they converge violently. The story ends with the black John watching a mob arrive for him, wondering if they brought "the coiling twisted rope."

Before that conclusion, however, Du Bois gives the reader a glimpse into the brutal illogics that crushed blacks' dreams about the possibilities of equal opportunities and the freedom to work and think unfettered. The town patriarch (white John's father) makes clear to the black John what the lines of demarcation are when it comes to blacks' education:

You and I both know, John, that in this country the Negro must remain subordinate, and can never expect to be the equal of white men. In their place, your people can be honest and respectful; and God knows, I'll do what I can to help them. But when they want to reverse nature, and rule white men, and marry white women, and sit in my parlor, then, by God! we'll hold them under if we have to lynch every Nigger in the land. Now, John, the question is, are you, with your education and Northern notions, going to accept the situation and teach the darkies to be faithful servants and laborers as your fathers were,-I knew your father, John, he belonged to my brother, and he was a good Nigger. Well—well, are you going to be like him, or are you going to try to put fool ideas of rising and equality in these folks' heads, and make them discontented and unhappy?

"Post-racial" sympathizers can read these excerpts and point out that Du Bois was writing, not today, but in a different era and under different circumstances - and they would be correct. Things have changed for the better in myriad ways since Du Bois published The Souls of Black Folk, but this does not mean that race no longer has a 
valence with powerful and often negative consequences. As we look around us in our "post-racial age," what exactly do we see? Just as Du Bois could perceive how education, labor, and violence were shaped by the way race mediated their articulation, we can look to the same spheres today and see that the color-line remains an effective means to understand the world.

We can look, for example, to federal courts that have insisted through a series of rulings that guidelines considering race for college and university programs must be "narrowly tailored," justified by a compelling state interest, and able to survive strict judicial scrutiny-vague prescriptions that have resulted in fewer racial minorities on our college campuses. ${ }^{11}$ As we survey the landscape beyond universities we also see a Supreme Court that is content to embrace tautologies that reckon away the broad role that race has played in jurisprudence. When, for example, in Parents Involved in Community Schools v. Seattle School District No. 1, Chief Justice John Roberts declared that the only "way to stop discrimination on the basis of race is to stop discriminating on the basis of race," he offered what seems like a commonsense, race-neutral assertion that actually ignores the repeated and deleterious effects that race-neutral policies and laws have had on non-white communities. ${ }^{12}$

In the world of labor we find race-neutral policies at play in southern states that are adopting strict laws to punish private employers who knowingly hire undocumented workers. These laws empower the state (police forces, public schools, public health-care systems) to monitor people who "appear" to be illegal immigrants and to deny public services to illegal immigrants. So far, the most aggressive of these laws is Alabama HB 56, the Beason-Hammon Alabama Taxpayer and Citizen Protection Act. When it was enacted in 2011, labor-intensive businesses (those that relied most heavily on migrant workers) began to lose their workforces as workers relocated instead of running the risk of being ticketed, imprisoned, or deported. In these southern states, appearance and field of labor are associated with illegality. ${ }^{13}$ 
In terms of violence all too many instances show that our "postracial age" - when we might hope to uncouple race and violenceremains just as prone to racial viciousness as ever. A steady stream of race-related mayhem, shootings, and murders is beamed to our flat-screen televisions and posted to the Internet for our consumption. Within the government, examples of state-sponsored and systemic violence-manifested in the stop-and-frisk policy of the New York City Police Department_-proves the lie behind the "post-racial" assertion. ${ }^{14}$ This policy, ostensibly race neutral, had a grotesquely disparate impact on non-white New York citizens. Following the stop-and-frisk protocols meant that black men between the ages of eighteen and twenty-four had a 7o percent chance of being stopped by the police; white males of the same age, a 13 percent chance. Close analyses of the stops show that they were not tied to suspected criminal behavior. In New York City people were stopped, regardless of class, because they were young black males. ${ }^{15}$ The great disparity in stops fostered paranoia among black residents regarding the police-a recipe for disaster. The black (and Latino) community increasingly refused to seek assistance even when help was actually needed, and the white community presumed that justice was being served since all of the cultural messages it received indicated that blacks were more prone to criminal behavior than whites. ${ }^{16}$

Chillingly, in the chapter "Of the Sons of Master and Man," Du Bois observed the same assumptions put into practice. Accusation was worth more than fact, and the end result was that blacks had no rights worth respecting and that whites had no reason to worry for blacks, only about them:

Daily the Negro is coming more and more to look upon law and justice, not as protecting safeguards, but as sources of humiliation and oppression. The laws that are made by men who have little interest in him; they are executed by men who have absolutely no motive for treating the black people with courtesy or consideration; and, finally, the accused law-breaker is tried, not by his peers, but too often by 
men who would rather punish ten innocent Negroes than let one guilty one escape.

Remember, this was written in 1903, not 2013.

The text in this book is, in fact, a reprint of the original 1903 version of The Souls of Black Folk. This version remained unchanged until 1953, when Blue Heron Press released a fiftieth-anniversary edition. Du Bois made a number of edits for the commemorative edition, the most notable of which was to delete references to Jews that could be construed as anti-Semitic. Du Bois also excised references to Yankee frugality. Although he made the changes on his own volition, we reprint the original version here as a reflection of $\mathrm{Du}$ Bois's mindset when he first crafted the book.

Even while we must place Du Bois's ideas in their proper historical context, we will find many as relevant today as at the time of their first publication. His insights into the nation's psyche tell us as much about our present as they do about the past. His deft interpretation of how social fundamentals_education, labor, violence_- "colored" his world needs little updating. Put another way, The Souls of Black Folk demonstrates that this country has yet to solve the racial riddles that are written into the nation's founding documents, ideologies, and practices. W. E. B. Du Bois, the brilliant son of Great Barrington, Massachusetts, the agitator of the nation's conscience, the citizen of Ghana, still speaks to us, to our condition, and to our humanity. It is critical that we listen.

\section{Notes}

1. Amy Bass, Those about Him Remained Silent: The Battle over W. E. B. Du Bois (Minneapolis: University of Minnesota Press, 209), 47.

2. The book was an amalgamation of previously published essays (or their extended versions) and new work prepared specifically for it. See David Levering Lewis, W. E. B. Du Bois: Biography of a Race, 1868-1919 (New York: Henry Holt, 1993), 277-78.

3. For powerful and often poignant examples of the current debates about racial citizenship, belonging, and the legacies of this country's racial logic see Ta-Nehisi 
Coates's series of articles in The Atlantic in 2013 and 2014. First are the exchanges that Coates had with an intellectual sparring partner, Jonathan Chait, about black culture and presumptions of pathology (see, for example, "Black Pathology Crowdsourced," "Other People's Pathologies," "Black Pathology and the Closing of the Progressive Mind"). These were followed by Coates's extended essay, "The Case for Reparations," all at http://www.theatlantic.com/ta-nehisi-coates. On contemporary debates about reparations beyond the United States see Jonathan Holloway, "Caribbean Payback: Europe's Former Colonies Battle for Slavery Reparations," Foreign Affairs, April 2, 2014, http://www.foreignaffairs.com/articles/14109o/jonathan-holloway/ caribbean-payback.

4. Bass, Those about Him Remained Silent, 14-21.

5. Alexander Crummell, "Civilization, the Primal Need of the Race," American Negro Academy, Occasional Papers, no. 3 (Washington, DC: American Negro Academy, 1898$), 6$.

6. Du Bois was not the only person to challenge Washington's accommodationist politics. Boston-based newspaper editor Monroe Trotter frequently attacked the Washington machine, as did others. Perhaps the earliest critic, however, was feminist Anna Julia Cooper. Cooper had been criticizing Washington and his rise to power a full decade before Du Bois published The Souls of Black Folk. In A Voice from the South: By a Woman from the South, published in 1892, Cooper argued that Washington's agenda would lead to a dead end for black Americans. A Voice from the South is a landmark text in the history of black feminist scholarship and embodies many of the same assimilationist and uplift ideologies that Du Bois trumpeted during his rise to prominence.

7. For publication information see M. Elaine Hughes, "A Selected Publication History of The Souls of Black Folk," in Dolan Hubbard, ed., The Souls of Black Folk: One Hundred Years Later (Columbia: University of Missouri Press, 2003), 323-25. These years also saw The Souls of Black Folk made part of a narrative trilogy about the black past. It was compiled with Booker T. Washington's Up from Slavery and James Weldon Johnson's An Autobiography of an Ex-Colored Man into Three Negro Classics, edited and introduced by John Hope Franklin (New York: Avon Press, 1965).

8. Adolph Reed, Jr., W. E. B. Du Bois and American Political Thought: Fabianism and the Color Line (New York: Oxford University Press, 1997), 92.

9. See, for example, Alfred Young, Jr., et al., The Souls of W. E. B. Du Bois (Boulder, CO: Paradigm Publishers, 20o6); Dolan Hubbard, ed., The Souls of Black Folk: One Hundred Years Later (Columbia: University of Missouri Press, 2003); Manning Marable, "Introduction," in W. E. B. Du Bois, The Souls of Black Folk (Boulder, CO: Paradigm Publishers, 2004); and Brent Hayes Edwards, "Introduction," in W. E. B. Du Bois, The Souls of Black Folk (New York: Oxford University Press, 2007).

10. Du Bois continued: "The worker must work for the glory of his handiwork, not simply for pay; the thinker must think for truth, not for fame. And all this is gained only by human strife and longing; by ceaseless training and education; by founding Right on righteousness and Truth on the unhampered search for Truth; by founding the common school on the university, and the industrial school on the common school; and weaving thus a system, not a distortion, and bringing a birth, not an abortion."

11. See, for example, Gratz v. Bollinger (2003), in which the Supreme Court declared that the University of Michigan's mechanism to diversify its student body violated the Equal Protection Clause and effectively discriminated against white ap- 
plicants; Grutter v. Bollinger (2003), in which the Supreme Court said that the University of Michigan's School of Law could use race as a factor in admissions provided that its use was "narrowly tailored"; and Fisher v. Texas (2013), in which the Supreme Court preserved affirmative action but emphasized that race could be used (and then with "strict scrutiny") only as a factor to secure diversity when race-neutral options were unsuccessful. The possibilities for race-based affirmative action receded even further in 2014, when the Supreme Court ruled in Schuette v. BAMN that federal courts could not intervene in state actions to eliminate race as a factor in college admissions. For a careful examination of the negative impact that race-neutral policies had on the racial and ethnic demographics of college campuses see David R. Colburn, Charles E. Young, and Victor M. Yellen, "Admissions and Public Higher Education in California, Texas, and Florida: The Post-Affirmative Action Era," InterActions: UCLA Journal of Education and Information Studies 4(1), 2008: 1-21.

12. George Lipsitz is particularly convincing on this issue in his book The Possessive Investment in Whiteness: How White People Profit from Identity Politics (Philadelphia: Temple University Press, 1998). In Schuette v. BAMN, Justice Sonia Sotomayor offered a scathing critique of Roberts's assertion in Parents Involved in Community Schools: "In my colleagues' view, examining the racial impact of legislation only perpetuates racial discrimination. This refusal to accept the stark reality that race matters is regrettable. The way to stop discrimination on the basis of race is to speak openly and candidly on the subject of race, and to apply the Constitution with eyes open to the unfortunate effects of centuries of racial discrimination. As members of the judiciary tasked with intervening to carry out the guarantee of equal protection, we ought not sit back and wish away, rather than confront, the racial inequality that exists in our society. It is this view that works harm, by perpetuating the facile notion that what makes race matter is acknowledging the simple truth that race does matter." Though a powerful indictment of historically innocent interpretations of how race resonates in society, Sotomayor's comments came in a dissent. In the current Court hers is a minority viewpoint.

13. In May 2014, New York Times correspondent Ian Urbina reported that the federal government was employing detained immigrants - almost half of whom were in the country legally but had been detained for a variety of reasons, often clerical error-as service workers in detention facilities across the country. These immigrants were overwhelmingly Latino and being paid no more than one dollar a day, a wage established for this kind of work in $195^{\circ}$ and never increased. Urbina, "Using Jailed Immigrants as a Pool of Cheap Labor," New York Times, May 24, 2014.

14. In May 2013, New York's stop-and-frisk practices were found to violate the Equal Protection Clause by US District Court judge Shira Scheindlin. Scheindlin's order, however, was stayed by the Second Circuit Court of Appeals on the ground that Scheindlin had violated the Code of Conduct and failed to be impartial in her deliberations. When Mayor Bill de Blasio took office in January 2014, he moved to settle the lawsuits related to the police department's stop-and-frisk policy and to end the practice. It is impossible to know how long it will take for the police department to repair the damage wrought by its policy.

15. Jeffrey Fagan, Amanda Geller, Garth Davies, and Valerie West, "Street Stops and Broken Windows Revisited: The Demography and Logic of Proactive Policing in a Safe and Changing City," Public Law and Legal Theory Working Group, Paper Number 09-203, Columbia Law School, June 2009, 44. 
16. As political scientist Vesla Weaver sadly concludes, the further we are removed from an "obviously" racial age (and thus the further we are into a "post-racial" one), the stronger the sensibility that race and crime are interlinked. "As our inglorious racial history is distanced with time," Weaver notes, "our punitive expansion becomes more separated from its racial motivations, and so too does the black crime narrative become ever more logical, assuming a factual, taken-for-granted quality in popular public opinion, media, and even academic narratives." Weaver, "Unhappy Harmony: Accounting for Black Mass Incarceration in a 'Post-Racial' America," in Frederick C. Harris and Robert E. Lieberman, eds., Beyond Discrimination: Racial Inequality in a Postracial Era (New York: Russell Sage Foundation, 2013), 247. 